\title{
Integration von Flüchtlingen in Deutschland und Österreich: Deutsch und Akkulturation
}

\author{
Gero Fischer
}

DOI: 10.21104/CL.2016.2.06

Integration of refugees in Germany and Austria: German and acculturation

\begin{abstract}
Abstrakt German for Foreigners (Deutsch als Fremdsprache) is an established field of German Studies which focuses on the methodology and didactics of teaching a language and a culture of communication. Should we want to refer to German used as the language of communication among immigrants living within a German-speaking environment, we need to talk about German as a Second Language (Deutsch als Zweitsprache). This suggests a communication level which is absolutely necessary for surviving in a foreign environment. Without sufficient proficiency in German, immigrants are limited in their chances of finding adequate employment and attaining additional qualifications. Speaking German is therefore essential for the integration and acculturation process. Knowledge of the English language is useful but absolutely insufficient for integrating into a Germanspeaking society. Attaining sufficient mastery of the German language is possible within a foreseeable time frame, but the integration process may take decades. The current immigration crisis has revealed serious shortcomings within the education system which have tended to be overlooked until now. The article describes the demands placed on educators and the actual situations the educators and relevant authorities are currently facing: mentoring children and young people; incidences of absolute (primary) illiteracy or inability to read the Roman alphabet,
\end{abstract}

etc. It has become apparent that only a minority of educators and language teachers have sufficient methodological and didactic background to be able to work with immigrants. Most of them have to rely on their own intuition, inspiration, and improvisation. The relevant authorities and politicians responsible have so far failed to provide adequate assistance and support, which is all the more serious considering that failure to integrate the immigrants would have immeasurable social and political consequences.

Keywords Role of Germans in integration, tasks of German lessons, quality of German courses, teacher training, social framework conditions.

Contact Prof. Dr. Gero Fischer, Institut für Slawistik, Universität Wien, Spitalgasse 2-4/Hof. 3, 1090 Wien, Austria; e-mail: gero.fischer@univie.ac.at

Jak citovat / How to cite Fischer, Gero. (2016). Integration von Flüchtlingen in Deutschland und Österreich: Deutsch und Akkulturation. Český lid 103, 265-284. doi:http://dx.doi.org/10.21104/CL.2016.2.06 


\section{Vorbemerkungen}

Deutschland und Österreich sind seit (mindestens) 1945 Zielländer von Flüchtlingen (1945 vertriebene Deutsche aus Osteuropa, 1948 kommunistische Machtergreifung in Osteuropa, 1956 Ungarn, 1968 Prager Frühling, 80-er Jahre Polenkrise, 1990-er Jahre Balkan-/Bosnienkrieg, Zerfall der Sowjetunion, ...). Österreich und insbesondere Wien hat in historischer Dimension von der Zuwanderung und von Flüchtlingsberwegungen profitiert - wirtschaftlich, kulturell, politisch. Wien bestand um 1850 aus $50-60 \%$ Zuwanderern, heute haben etwa 45\% der Wiener sogenannten Migrationshintergrund. In Wien werden ca 120 Sprachen gesprochen, usw. Wien ist offener, europäischer, in gewisser Hinsicht globaler geworden. Entscheidend für eine erfolgreiche Integration sind aber die Bedingungen, die die Zuwanderer vorfinden (insbesondere Saunders 2011).

Der vorliegende Artikel beschäftigt sich mit der Frage, mit welchen Problemen der Erwerb / die Vermittlung des Deutschen mit dem Prozess der Akkulturation und Integration in der aktuellen Flüchtlingsfrage verbunden ist.

\section{Deutsch - Voraussetzung zur Eingliederung in die Gesellschaft}

Es ist eine nahezu triviale Feststellung, dass an der Spitze der Prioritäten der Erwerb bzw. die Vermittlung des Deutschen steht, es ist die Grundlage, um überhaupt in einem deutschsprachigen Land an der Gesellschaft teilnehmen zu können. Was so einfach und logisch erscheint, erweist sich im Detail als durchaus komplex: Wenn man die soziokulturellen Umstände der Zuwanderer berücksichtigt, ihre schulische Sozialisation, dann eröffnet sich eine große Spannweite sprachdidaktischer und sprachpädagogischer Aufgaben, für die die meisten Lehrenden von ihrer Ausbildung her in der Regel nicht vorbereitet sind.

Die Voraussetzungen für den Erwerb des Deutschen, die Migranten bzw. Flüchtlinge mitbringen, sind völlig uneinheitlich. Beim Erlernen des Deutschen als Zweitsprache bzw. als Verkehrssprache geht es nicht um eine Fremdsprache, die man (vielleicht) einmal im Urlaub ein bisschen verwendet, sondern hier ist Deutsch das zentrale Kommunikationsmittel für das Überleben im Alltag, im Beruf, in der Gesellschaft. Viele Zuwanderer beherrschen zwar mehr oder weniger gut Englisch, aber für eine erfolgreiche Integration, ein „Ankommen“ in der deutschsprachigen Gesellschaft in Österreich oder in Deutschland ist dies völlig unzureichend.

Das Erlernen einer Sprache ist von den Inhalten des Lernprozesses nicht zu trennen. Deshalb sind auch gängige (auf dem Markt erhältliche) Lehr- / Lernmaterialien in der Regel nur bedingt geeignet, weil sie für andere Zielgruppen (z.B. Studierende, gebildete Mittelschicht mit kurz-/mittelfristiger Aufenthaltsperpektive, Touristen, o.ä.) konzipiert sind. Wieviel Deutsch und „welches“ sollen die künftigen „Neubürger“ erlernen, die Schrift-l 
Standardsprache, die Umgangssprache? Ein Ausländer, der mittelfristig zum Inländer werden will, muss sich auf Deutsch bei Behörden, beim Arbeitsamt u.ä. verständlich machen können, muss in der Lage sein, Verträge zu verstehen, Inserate aufgeben und lesen können etc. Alles Domänen und Aufgaben, mit denen ein durchschnittlicher Tourist so gut wie nie in Berührung kommt. Dem Deutschunterricht kommt die Aufgabe zu, den Fremden die sprachlichen Instrumente in die Hand zu geben, um in allen möglichen sozialen und kommunikativen Kontexten bestehen zu können. Das schließt auch ein, dass z.B. im Deutschunterricht konkret Themen wie Wohnungssuche, Behördenwege, Arbeitsmarkt, Bewerbungen, bürgerliche Rechte und Pflichten, Bildungssystem, Toleranz, Religionsfreiheit usw. behandelt werden, d.h. buchstäblich „zur Sprache kommen“ und diskutiert werden. Auch die Zuwanderer selbst werden viele Fragen betreffend die ihnen fremden Lebensformen stellen, auf die sie Antworten wissen wollen. Damit wird im Deutschunterricht konkrete Integrationsarbeit geleistet. Gewandtheit, Sicherheit, grammatische Richtigkeit in der Sprache erwirbt man weniger durch Instruktion sondern vor allem durch Praxis, durch den alltäglichen Sprachkontakt. Wie „gut“ jemand die Zielsprache erwirbt und beherrscht, ist von vielen außerpädagogischen Faktoren abhängig (Bildungsstand, soziokultureller Kontext, Einbindung in die Aufnahmegesellschaft, berufliche Tätigkeit, etc.). Der Grad der Beherrschung des Deutschen bestimmt für die Zuwanderer die Qualität der Wahrnehmung der Umwelt und stellt für sie insoferne einen Akt der Befreiung und Selbständigkeit dar, indem sie eine Stimme erhalten und sich äußern können.

Der Deutschunterricht alleine kann sicherlich nicht alle Kommunikationsbedürfnisse abdecken. Wichtig sind Vorbilder, Muster, an denen sich die Migranten orientieren können. D.h. hier ist die Aufnahmegesellschaft gefordert, sich aktiv am Integrationsprozess zu beteiligen, der in Wirklichkeit ein Dialog ist zwischen Einheimischen und denjenigen, die dazugehören wollen. Der Staat ist gefordert, infrastrukturelle Bedingungen zu schaffen, die den Integrationsdialog unterstützen. Die Zuwanderer müssen möglichst bald die Chance erhalten, in das Gesellschaftsleben eingebunden zu werden, neben (bezahlter) Arbeit auch durch Gesprächszirkel, Konversationsrunden, organisierte Ausflüge, Stadtspaziergänge, Konzertbesuche, Einbindung in Sport-, Theater- und Musikgruppen usw.

Der Informationsbedarf der Zuwanderer ist vielfältig, daher wären offizielle, d.h. unter staatlicher Regie spezielle professionelle Integrationsberatungsstellen mit Personen zu installieren, die selbst migrantischer Herkunft sind und die Anpassungs- und Lernprozesse schon durchgemacht haben. Diese Integrationsberater können authentische und kompetente Ansprechpartner für Migranten und Flüchtlinge sein und Wissensdefizite, Missverständnisse bezüglich der Aufnahmegesellschaft beheben bzw. bereinigen helfen. Bisher gibt es nur vereinzelte Angebote (unterschiedlicher Qualität) der Zivilgesellschaft auf freiwilliger Basis, was den Bedarf bei Weitem nicht deckt. 


\section{Zum Prozess des Deutscherwerbs}

Rechtlichen Anspruch auf (kostenlose) Deutschkurse haben nur Personen mit offiziell anerkanntem Asylstatus. Asylwerber haben keinen Anspruch auf kostenlose Kurse, sie dürfen auch nicht arbeiten, müssen aber im Schnitt viele Monate (bis zu mehreren Jahren) auf eine definitive Entscheidung über ihren Asylstatus warten. Die Finanzierung der kostenpflichtigen Deutschkurse muss in der Regel von humanitären Organisationen oder Privatpersonen getragen werden. Der Staat wälzt also Aufgaben, für die er grundsätzlich zuständig ist, auf die Zivilgesellschaft ab und erspart sich somit erhebliche finanzielle und personelle Ressourcen. Die unsichere und auf längere Zeit unklare Aufenthaltsperspektive wirkt sich auf die Motivation der Flüchtlinge zum Deutscherwerb negativ aus: Wozu intensiv Deutsch lernen, wenn letzten Endes doch die Abschiebung droht?

Das Angebot an Deutschkursen ist insgesamt weder quantitativ (es gibt Wartelisten und überfüllte Kurse) noch qualitativ ausreichend. Hauptsächlich bieten Volkshochschulen, karitative Organisationen und kommerzielle Sprachschulen entsprechende Kurse an. Es sind unterschiedliche sprachpädagogische Aufgaben zu bewältigen: Die Vorbildung der Flüchtlinge umfasst eine große Bandbreite von nicht vorhandener Schulbildung / Analphabetismus bis zu Universitätsabschluss. Vielen Kursleitern mangelt es jedoch an professioneller Ausbildung (Deutsch als Fremdsprache). Sie verfügen nur über ein begrenztes methodologisches Repertoire, können sich an die konkret gegebenen Anforderungen nicht anpassen bzw. keine adäquaten Zugänge verschaffen und praktizieren bestimmte eingelernte Routinen und Schablonen, oftmals gegen die Voraussetzungen und Bedürfnisse der Kursteilnehmer. Gar nicht so selten werden völlig veraltete und inadäquate didaktische Methoden praktiziert, indem z.B. Grammatikterminologie (die oft auf die Herkunftssprachen gar nicht anwendbar ist), formale sprachliche Richtigkeit forciert, die Aussprache aber vernachlässigt, lebensferner Wortschatz gelernt wird und die notwendige kommunikative Kompetenz für den Alltag zu kurz kommt. Wenn Deutsch zugleich Unterrichts-, Ziel- und Metasprache (Sprache der Erklärungen) ist, dann kummulieren sich die Schwierigkeiten: Allgemein ist die Semantisierung abstrakter Begriffe weitaus schwieriger als bei konkreten Begriffen, die z.B. über bildliche Darstellungen ausreichend eindeutig erklärt werden können. Dasselbe gilt auch von Wörtern mit vorwiegend grammatikalischer Funktion, komplexen syntaktischen oder soziokommunikativen Konstruktionen, aber auch von der Höflichkeitssprache (der Gebrauch von Du und Sie), Grußformeln, usw. Die Vermittlung und Erklärung grammatischer wie soziokommunikativer Phänomene ausschließlich über die Metasprache Deutsch bleibt auf Grund der mangelnen Deutschkenntnisse der Kursteilnehmer zwangsläufig oft lückenhaft, ungenau und führt zu zahlreichen zu Missverständnissen. Viele Kursteilnehmer sind es auch nicht gewöhnt mit Wörterbüchern oder 
Nachschlagewerken zu arbeiten, sondern verlassen sich auf die dürftigen (und nicht selten fehlerhaften) Angaben von google-translate. In solchen Fällen wäre der Rückgriff auf die jeweilige Muttersprache hilfreich, um subtile Bedeutungsunterschiede, Besonderheiten der Sprachstrukturen des Deutschen deutlich machen und herausarbeiten zu können. Hier wären kontrastive bzw. konfrontative didaktische Verfahren sinnvoll. Dazu müssten aber die Lehrkräfte über die entsprechende Ausbildung verfügen, am besten würden sich dafür zweisprachige (Deutsch -Herkunftssprache) Sprachlehrer eignen. Potenzial wäre aber zweifellos vorhanden: Es ist anzunehmen, dass sich unter den Flüchtlingen auch Lehrer befinden, die ohne Weiteres diese Aufgaben wie auch die der Primäralphabetisierung realisieren könnten.

\section{Analphabetismus und Niveau der Beherrschung der Herkunftssprache}

Auch in europäischen Gesellschaften gibt es einen gar nicht so geringen Prozentsatz von (sog. funktionalen) Analphabeten (in Österreich geschätzt mehrere Hundert Tausend). Es handelt sich also um Personen, denen es nicht gelungen ist trotz Schulbesuch Lesen und Schreiben zu lernen bzw. die diese Fertigkeiten später wieder / oder weitgehend verlernt haben. Für diesen Personenkreis werden schon seit Jahren spezielle Alphabetisierungskurse insbesondere an Volkshochschulen angeboten. Der wesentliche Unterschied zu analphabetischen Zuwanderern ist, dass die „einheimischen“ Analphabeten Deutsch beherrschen und sie „nur“ die Kulturtechnik Lesen und Schreiben (wieder) erlernen müssen, was schwer genug ist. Bei den Flüchtlingen / Migranten stellt sich das Problem des Analphabetismus komplexer dar: Im einfacheren Fall beherrschen sie bloß das lateinische Alphabet nicht, sie sind z.B. in arabischer Schrift alphabetisiert. In so einem Fall lernen sie die Lateinschrift im Kontext des Deutschunterrichts. Weitaus komplizierter ist der Fall, wenn die betroffenen Personen überhaupt nicht alphabetisiert wurden, weil sie nie eine Schule besucht haben. In so einem Fall müssen sie primär alphabetisiert werden, das funktioniert aber nur in ihrer Muttersprache (Farsi, Pashto, Kurdisch, Arabisch u.a.). Jetzt kann es aber (übrigens gar nicht so selten) sein, dass die Betroffenen die Standardsprache nicht beherrschen, sondern einen Dialekt (oder eine nicht verschriftlichte Minderheitensprache) sprechen. Dann müssen sie erst einmal als Dialektsprecher die (geschriebene) Standardsprache (Aussprache, Funktionen der Buchstaben, Orthographie, Grammatik, Erweiterungswortschatz, etc.) erlernen um primär alphabetisiert werden zu können. Wer nicht alphabetisiert ist, keine Schule besucht hat, verfügt auch über keine Erfahrung im Umgang mit Schreibzeug, hat die Feinmotorik nicht entwickelt - und allgemeiner noch - hat überhaupt das Lernen nicht gelernt etc. D.h. die nachzuholende Primäralphabetisierung hat nicht bloß linguistische Aufgabenzu lösen sondern in gewissem Rahmen auch Akkulturation zu leisten. 
Nachholende Alphabetiseirung ist deshalb eine so wichtige Aufgabe, weil sie die Voraussetzung für die weitere berufsspezifische Ausbildung darstellt. Der Aufwand ist beträchtlich und man muss damit rechnen, dass dieser Alphabetisierungsprozess mehrere Jahre in Anspruch nehmen wird. Andernfalls können diese Personen keine Qualifikationen erwerben, die ihnen die materielle Existenz sichern, sie werden mit Sicherheit von der Sozialhilfe abhängig bleiben.

Viele Flüchtlinge (je nach Herkunftsland gibt es deutliche Unterschiede) haben kaum mehr als die Grundschule absolviert, das ist oft nicht viel mehr als 6 Jahre. Personen mit abgeschlossener Schulbildung, Hochschulbildung machen naturgemäß pädagogisch die geringsten Probleme beim Erwerb des Deutschen und bei der weiterführenden Ausbildung. Wesentlich mit dem Bildungsgrad hängt die Lesefähigkeit zusammen. Lesenkönnen und Leseerfahrung sind eine Grundvoraussetzung für den weiteren Bildungsweg. Personen ohne ausreichende Leseerfahrung in ihrer Muttersprache werden auf Deutsch dieses Defizit kaum ausgleichen oder nachholen können. Sie werden auch nicht in der Lage sein, verschiedene schriftsprachliche stilistische Varianten und Textsorten kennen und verstehen zu lernen. Damit sind die Grenzen ihres Spracherwerbs abgesteckt und die Möglichkeiten ihrer weiteren beruflichen Qualifizierung entsprechend beschränkt.

\section{Rolle des Englischen und anderer „Brückensprachen“}

Die Möglichkeit sog. Brückensprachen im Unterricht einzusetzen ist unterschiedlich gegeben: Auch wenn viele Flüchtlinge in einem gewissen Ausmaßs über Englischkenntnisse verfügen, so sind diese oft zu gering, als dass sie für den Erwerb des Deutschen von Vorteil wären. Häufig entsteht aber das Problem, dass es auf Grund der Sprachverwandtschaft zwischen dem Englischen und dem Deutschen zu störenden Interferenzen zwischen den beiden Sprachen kommt. Die Verwendung von „Brückensprachen“ als Hilfssprachen (d.h. als Metasprachen) ist dann von Vorteil, wenn sie von den Kursteilnehmern gut beherrscht werden und dann in konkreten Fällen effektiver als das Deutsche die Funktion der Metasprache übernehmen können.

Nicht vergessen werden soll die Problematik von Übersetzung und Dolmetschen bestimmter Herkunftssprachen. Es gibt einen ausgesprochenen Mangel an qualifizierten Übersetzern und Dometschern aus Farsi, Pashto, Kurdisch, afrikanischen Sprachen. Häufig fungieren Personen mit Migrationshintergrund, die schon lange im Lande leben, auch offiziell (d.h.im Verkehr mit Behörden) als Übersetzer / Dolmetscher allerdings ohne entsprechenden Qualifikationsnachweis. Ob und inwieweit sie noch ihre Muttersprache gut beherrschen und ob sie wirklich in der Lage sind korrekt zu übersetzen, bleibt häufig unklar und de facto unüberprüfbar. Welche Rolle sie in offiziellen Funktionen (z.B. als Dolmetscher) spielen und wieweit 
sie dabei persönliche Interessen vertreten, ist wenig untersuchte Frage. Qualität und Zuverlässigkeit von Übersetzungen und Dolmetschungen haben weitreichende Folgen beginnend mit der Registrierung von Flüchtlingen bis zu den Interviews, die die Grundlage für die Entscheidung über den Asylstatus bilden. Eden Mengis (2015) ist in einer Studie über Übersetzer / Dolmetscher aus Tigrinya (Eritrea) dieser Frage nachgegangen und hat nicht nur erhebliche Mängel sondern auch Manipulationen (in extremen Fällen sogar Drohungen und politischen Druck seitens der eritreischen Auslandsvertretung) festgestellt.

Es könnte aber die moderne Kommunikationstechnologie zumindest teilweise Abhilfe schaffen: Im österreichischen Gesundheitswesen setzt sich neuerdings das so genannte Video-Dolmetschen (über Video wird ein Dolmetscher eingeschaltet, der zwischen Arzt und Patienten übersetzt) immer mehr durch, es bewährt sich sehr gut. Analog dazu wäre bei der Kommunikation zwischen Behörden und Flüchtlingen auch eine Vernetzung mit deutschen und schweizer Sprachexperten denkbar mit dem Zweck das Potenzial von Spezialisten zu erweitern, auf die zurückgegriffen werden könnte. Hier wird offensichtlich, dass die Kürzung und Streichung, ja auch die Diffamierung von Studienrichtungen orientalischer Sprachen ein Fehler war und ist, weil es zu wenig Personen gibt, die außereuropäische Sprachen gut beherrschen.

\section{Schulpflichtige Migranten - die österreichische Praxis}

In Österreich wird schon seit vielen Jahren das Prinzip der altersgemäßen Einschulung mit Übergangsfristen vertreten (d.h. die Schüler haben zwei Jahre Zeit, die entsprechenden Prüfungen abzulegen), die guten Erfahrungen bestätigen die Richtigkeit dieses Zuganges. Der von Rechtsparteien losgetretene Disput über eigene (d.h. segregierte) Flüchtlingsklassen entspringt einer populistischen Profilierungssucht um jeden Preis und wird von Migrationspädagogen rundum abgelehnt. Das hindert dogmatische und erkenntnisresistente Politik nicht daran, trotzdem dieses Ziel zu verfolgen, weil sie vor allem in Wirklichkeit Segregation und Diskriminierung beabsichtigen und nicht Integration von Zuwanderern mit dem Ziel eines gleichberechtigten Miteinanders in der Gesellschaft.

Die altersgemäße Einschulung endet jedoch mit dem Alter von15 Jahren: Jugendliche haben ab diesem Zeitpunkt keinen Anspruch mehr auf Schulbesuch und damit kaum eine Chance die Pflichtschule nachzuholen. Damit haben sie auch keine Möglichkeit z. B. ein Handwerk zu erlernen, wofür die abgeschlossene Pflichtschule die Voraussetzung ist. Diese Inflexibilität des österreichischen Schulsystems stellt sich als ernstes Problem mit weitreichenden sozialen Folgen auf dem Weg zur Integration dar. 


\section{Lernziel „Integration“?}

Kann „Integration“ Gegenstand eines pädagogischen Programmes, eines Curriculums sein? Kann „Integration“ (wie ein Gegenstand) unterrichtet/ gelernt werden? Das Problem liegt schon im Begriff, wie beschreibt bzw. definiert man „Integration“? Was ist alles Gegenstand der Integration und wann ist sie abgeschlossen? Die Diskussionen dazu verlaufen widersprüchlich. Häufig werden historische Erfahrungen ignoriert. Deutschland hat nach 1945 12 Millionen Menschen (Vertriebene aus Osteuropa) aufgenommen und integriert, Österreich hat große Zuwanderungswellen schon im 19. Jh. erlebt (insbesondere nach Wien: Tschechen, Juden usw.). Ökonomisch und demographisch hat die Migration längerfristig Vorteile gebracht, sie hat keineswegs zu einer ethnischen oder kulturellen Überfremdung geführt, wie nationale Nostalgiker und Hetzer immer wieder betonen wollen. Vielmehr wird auch durch den Blick auf die eigene Familiengeschichte klar, dass nationale, kulturelle Homogenität in der Geschichte wie in der Gegenwart eine Fiktion und darüber hinaus ein falsches Ideal ist (Saunders 2012).

Wie schon erwähnt, nimmt das Erlernen einer Fremdsprache auf sehr hohem Niveau Jahre in Anspruch. Nicht alle Zuwanderer erreichen im Laufe ihres Lebens das Niveau fehlerfrei schriftlich wie mündlich kommunizieren zu können. Viele werden einen bestimmten Grad der Sprachbeherrschung nicht überschreiten (können). Welchen zeitlichen Rahmen müssten wir aber bei der Integration annehmen?

Die Politik hat sich im Zusammenhang mit der Integrationsproblematik obligatorische Intensivkurse in Sachen Integration ausgedacht, in denen ein Katalog von europäischen „Werten“ (in der Tat von Demokratie bis zu Frauenrechten und Mülltrennung) abgearbeitet werden soll (in Bayern werden dazu 3 Stunden, in Österreich 8 benötigt). Methodologisch ist das vergleichbar mit einem Sprachunterricht, in dem die Grammatikregeln einmal in Intensivform präsentiert werden und zu glauben, dass das genügt. Das Einüben in sprachliche und / oder gesellschaftliche Konventionen erfolgt durch die (Lebens-)Praxis, es ist dies eine Art Trial-and-error-Methode, in der vieles einfach einmal ausprobiert werden muss, und die viele Fehler zulässt, ja zulassen muss. Abgesehen von der aufoktroyierten dubiosen pädagogischen und lerntheoretischen Problematik unterstellt die Politik, dass die Flüchtlinge mit dem Ziel gekommen sind, sich vorsätzlich außerhalb der Normen zu verhalten. Derzeit ist es aber so, dass die demokratischen Werte real durch brennende Asylheime, Hetzparolen von Pegida, AfD u.a. rechtsradikalen politischen Gruppen ständig unterlaufen werden. Die bewusste Vermengung der Flüchtlingsproblematik mit dem islamistischen Terror ist mutwillige Hetze und ein Instrument generell Flüchtlinge zu diskriminieren. Dass auf Grund der konkreten Lebensbedingungen (Massenquartiere, Arbeitsverbot, mangelnder gesellschaftlicher Anschluss, Ablehnung durch die 
Bevölkerung, wachsende Perspektivelosigkeit etc.) jugendliche Flüchtlinge auch Gesetzesübertretungen (Diebstähle, sexuelle Übergriffe udgl.) begehen können, darf nicht verwundern. Vorurteile und Abwehrreaktionen gegen Zuwanderer und Flüchtlinge begleiten alle Immigrationswellen, in der Innenpolitik missbrauchen immer wieder konservative und nationalistische politische Parteien die Zuwanderung für eigene Zwecke. Sie benutzen Vorurteile, betreiben mehr oder weniger subtile Hetze gegen Ausländer, Asylanten, diffamieren humanitäre Hilfe etc. fordern besonders restiktive Sondergesetze etc. Dabei sind Rückgriffe auf Nazi-Parolen und NS-Sprache häufig beobachtbare Praxis. Gefährlich an diesen Diskursen ist, dass die Sprache populistischer und rassistischer Hetze immer offensiver, gesellschaftsfähig und aller bisherigen gesellschaftlichen Tabus entkleidet wird.

Integration ist ein Prozess, der mehrere Jahre dauert, abhängig vom Bildungsgrad, Sozialstatus etc. der Zuwanderer. Dieser Prozess lässt sich kaum verkürzen. Integration ist ein Dialog der Einheimischen mit den Zuwanderern. Gesellschaftliche „Werte“ werden dialogisch angenommen bzw. „erlernt“ dadurch, dass die Zuwanderer in der neuen Umwelt das Eigene mit dem Fremden konfrontieren und das Neue für sich adaptieren. Umgekehrt lernen auch die Einheimsichen von den Zuwanderern: „Kultur“ ist keine Konstante, sie ist zahlreichen Veränderungen unterworfen und selbstverständlich hinterlassen Migrationen ihre Spuren. Der Kontakt zwischen Einheimischen und Fremden prägt sich in der Sprache und in vielen Bereichen der Alltagskultur ein. Im Prozess der Integration der Fremden verändert sich auch die Kultur der Einheimischen und das war schon immer so. Sieht man sich die Spuren der Kontakte mit dem Fremden in der Kulinarik, Umgangssprache, bei Namen etc. an, so kann man sich von der Wirksamkeit dieser gegenseitig wirksamen Mechanismen ein beeindruckendes empirisches Bild machen. Aus populistischen und demagogischen Gründen werden diese Prozesse der gegenseitigen Beeinflussung oft nicht zur Kenntnis genommen bzw. sogar verleugnet oder dämonisiert (von Entfremdung, Majoriserung durch die Fremden ist die Rede). Integration heißt für den Zugewanderten Eintritt in eine neue Gesellschaft und für die Einheimischen die Bereitschaft, die „Neuen“ als Gleichberechtigte aufzunehmen.

Integration ist ein langandauernder Lernprozess, in dem sich Zuwanderer wie Einheimische die Rollen teilen. Zuwanderer orientieren sich am Alltag, an der gelebten Praxis, an (Vor-)Bildern und den ihnen gebotenen Möglichkeiten am gesellschaftlichen Leben teilzunehmen. Wenn man davon ausgeht, dass mit etwa 2-5 Jahren Aufenthaltsdauer die Deutschkenntnisse als gut bezeichnet werden können (was nicht Mängel, Lücken, Fehler ausschließt), dann wird klar, dass Integrationsprozesse Jahrzehnte beanspruchen können. Wer kann schon „wirklich perfekt“ Deutsch, wer ist schon „wirklich perfekt“ integriert? So vage die Fragestellung auch ist, die Frage nach der Sprachbeherrschung ist wahrscheinlich leichter und objektiver zu beantworten als die nach dem Grad der Integration. Sicher ist auch, dass sprachliche Fehler, Verstöße gegen 
die grammatischen Regeln oder gegen die konventionelle Sprachpraxis eher tolerabel als Verstöße gegen gesellschaftliche Konventionen erscheinen.

Auch beim Integrationsprozess (wie beim Lernen überhaupt) hat der Faktor der Motivation seinen Platz. Sie kann durch verschiedene Umstände beeinflusst werden, negativ wie positiv. Zu den negativen Faktoren gehören insbesondere mangelnde Akzeptanz der Fremden durch die einheimische Bevölkerung und fehlende Perspektive eines dauernden (unbefristeten) Aufenthalts mit der Möglichkeit des Familiennachzugs. Letztere Frage wird zur Zeit unter dem Titel „Asyl auf Zeit“ (3 Jahre) diskutiert und selbst von Kreisen der Wirtschaft abgelehnt. Die Eingliederung in den Arbeits- und Erwerbsprozess ist aktuell bei stagnierender Wirtschaftsentwicklung, hoher heimischer Arbeitslosigkeit sehr schwierig, wobei die Frage der Qualifikation, der Ausbildung der Flüchtlinge eine besonders harte Nuss darstellt. In Schulungen, Qualifikationskurse etc. müssen erhebliche Mittel investiert werden, um die Arbeitslosigkeit insgesamt (Einheimische und Zuwanderer) nicht weiter explodieren zu lassen.

\section{Schlussbemerkungen}

Im Verlauf des Integrationsprozesses hat der Erwerb des Deutschen eine vorrangige Stellung. Die offizielle Politik reagiert bei der Integrationsarbeit konzept- und ratlos, zeigt geringe Professionalität und neigt zu oberflächlichen (meist populistischen) Ad hoc-Lösungen. Sie unterstellt absurder Weise und entgegen alle Empirie, dass sich ein Großteil der Flüchtlinge und Zuwanderer absichtlich dem Deutschen verweigert und so bewusst und zielsicher dem Rand der Gesellschaft zustreben will. Die Zivilgesellschaft agiert hingegen wesentlich kompetenter und bereitwilliger, sie benötigt aber staatliche Unterstützung in vielen Bereichen. Wichtiger als Intensivkurse in Sachen Integration wären Beratungsstellen mit bereits integrierten muttersprachlichen Fachkräften, die über alle Bereiche des Alltagslebens zuverlässige Informationen geben können, z.B. über Arbeitsrecht, Wohnen, Miete, Schulen, Kredite, etc. Dass es unter den Flüchtlingen und Migranten Menschen gibt, die sich sozialen Anpassungen (aus den verschiedensten Gründen) grundsätzlich verweigern, soll keineswegs abgestritten werden, aber diese Personengruppen stellen eine absolute Minderheit dar. Für ausgesprochen deviantes und gesetzwidriges Verhalten gibt es die entsprechenden staatlichen Sanktionen und Machtmittel. Die Politik ist aber aktuell ganz wo andershin unterwegs: Sie sucht intensiv Möglichkeiten, die Integration der Flüchtlinge eher anderen Ländern aufzubürden. Das ist - allen ihren Beteuerungen christlicher Werte zum Trotz - unsolidarisch und für die Betroffenen unmenschlich und zerstört die humanistischen und demokratischen Ziele der EU. 


\section{Literatur}

Fischer, Gero. 2015. Nebeneinander statt miteinander? Zum aktuellen Integrationsdiskurs. Retrieved from: http://slawistik.univie.ac.at/forschung/ fd/forum-fuer-hochschuldidaktikund-hochschulpolitik/.

Mengis, Eden. 2015. „Sprich nicht so über dein Land!“ Tigrinya-Dolmetscher in Anhörungen vor dem Bundesamt für Migration und Flüchtlinge. Moderne Sprachen 59, 1: 7-48.

Saunders, Doug. 2011. Arrival City. How the Largest Migration in History is Reshaping Our World. London. Saunders, Doug. 2012. Mythos Überfremdung. Eine Abrechnung. München. (Original: The Myth of a Muslim Tide - Do Immigrants Threaten the West? 2012. Toronto.)
Pflichtenheft für Flüchtlinge und Migranten: Der Integrationsplan. 2015. Retrieved from: http://slawistik.univie. ac.at/forschung/fd/forum-fuerhochschuldidaktik-und-hochschulpolitik/.

Zur Integration von Migranten und Flüchtlingen ins österreichische Bildungswesen - Deutsch u.a. Herausforderungen. 2015. Retrieved from: http://slawistik.univie. ac.at/forschung/fd/forum-fuerhochschuldidaktik-und-hochschulpolitik/. 


\section{Integrace uprchlíků v Německu a Rakousku: němčina a akulturace}

\section{Úvodní poznámky}

Německo a Rakousko jsou (minimálně) od roku 1945 cílovými zeměmi pro uprchlíky (1945 odsun Němců z východní Evropy, 1948 uchopení moci komunisty ve východní Evropě, 1956 Mad’arsko, 1968 Pražské jaro, 80. léta polská krize, 90. léta válka na Balkáně / v Bosně, rozpad Sovětského svazu...). Přistěhovalectví a pohyb uprchlíků byly z historického pohledu pro Rakousko, zejména pak Vídeň, hospodářským, kulturním i politickým přínosem. V roce 1850 tvořili přistěhovalci 50-60 \% vídeňského obyvatelstva, dnes má zhruba 45 \% Vídeňanů tzv. migrační pozadí. Ve Vídni se mluví zhruba 120 jazyky. Vídeň je dnes otevřenější, evropštější, v jistém ohledu globálnější. Pro úspěšnou integraci jsou však rozhodující podmínky, do nichž přistěhovalci přicházejí (viz zejména Saunders 2011).

Tento článek se zabývá otázkou, s jakými problémy v rámci aktuální uprchlické situace se potýká osvojování/výuka němčiny a proces akulturace a integrace.

\section{Němčina - předpoklad pro začlenění do společnosti}

Tvrzení, že osvojení, popřípadě výuka němčiny představuje absolutní prioritu, zní téměř triviálně. Jedná se o základ, díky němuž se můžeme v německy mluvící zemi vůbec účastnit společenského života. Tato na první pohled jednoduchá a logická skutečnost se však při bližším pohledu jeví mnohem komplexněji. Zohledníme-li sociokulturní okolnosti přistěhovalců a jejich školní socializaci, otevře se široké spektrum jazykově didaktických a pedagogických úkolů, na které většina vyučujících zpravidla nebyla v rámci studia připravována.

Migranti či uprchlíci přicházejí s naprosto různorodými předpoklady pro osvojení němčiny. Při učení němčiny jako druhého, popřípadě dorozumívacího jazyka nejde o cizí jazyk, který (možná) jednou použijeme na dovolené. Němčina zde představuje ústřední komunikační prostředek nezbytný pro přežití v každodenním životě, v práci, ve společnosti. Mnoho přistěhovalců sice ovládá více či méně dobře angličtinu, pro úspěšnou integraci, začlenění do německy mluvící společnosti v Rakousku či Německu to však je naprosto nedostatečné.

Osvojování jazyka nelze oddělit od obsahu procesu učení. Proto také běžné (na trhu dostupné) výukové/studijní materiály nejsou zcela vhodné, nebot' jsou koncipovány pro jiné cílové skupiny (studenty, vzdělanou střední vrstvu 
se zaměřením na krátkodobý/střednědobý pobyt, turisty apod.). Kolik němčiny a „jakou“ němčinu se mají budoucí „noví občané“ naučit, spisovný/standardní jazyk, hovorový jazyk? Cizinec, který má ve střednědobém výhledu náležet k domácímu obyvatelstvu, se musí německy dorozumět na úřadech, například na úřadu práce, musí být schopen porozumět smlouvám, zadávat a číst inzeráty apod. To všechno jsou oblasti a úkoly, s nimiž průměrný turista prakticky nepřijde do styku. Úkolem výuky němčiny je poskytnout cizincům jazykové nástroje, díky nimž obstojí ve všech myslitelných sociálních a komunikačních kontextech. Proto se při výuce němčiny musí probírat konkrétní témata, jako je hledání bydlení, pochůzky po úřadech, trh práce, žádost o zaměstnání, občanská práva a povinnosti, vzdělávací systém, tolerance, náboženská svoboda atd. Znamená to, že se tato témata skutečně „dostanou ke slovu“ a diskutuje se o nich. I sami přistěhovalci kladou řadu otázek týkajících se forem života, které jsou jim cizí, a chtějí znát odpovědi. Při výuce němčiny tak probíhá konkrétní integrační práce. Jazykovou obratnost, jistotu vyjadřování i gramatickou správnost si lze osvojit především v praxi, při každodenním kontaktu s jazykem, spíše než prostřednictvím instruktáže. Skutečnost, jak „dobře“ si někdo cílový jazyk osvojí a dokáže ho ovládat, závisí na řadě faktorů nesouvisejících s pedagogickým procesem (na dosaženém vzdělání, sociokulturním kontextu, zapojení se do přijímající společnosti, povolání apod.). Stupeň osvojení němčiny migranty určuje kvalitu jejich vnímání prostředí a dodává jim svobodu a samostatnost tím, že získají „vlastní hlas“ a mohou se vyjadřovat.

Výuka němčiny sama o sobě jistě nemůže pokrýt veškeré komunikační potřeby. Důležité jsou příklady, vzory, podle nichž se mohou migranti orientovat. Je tedy potřebné, aby se přijímající společnost aktivně účastnila integračního procesu, který je ve skutečnosti dialogem mezi domácím obyvatelstvem a těmi, kteří se chtějí stát jeho součástí. Je třeba, aby stát vytvořil infrastrukturní podmínky, které integrační dialog podpoří. Přistěhovalci musí dostat co nejdříve šanci zapojit se do společnosti, vedle (placené) práce také v podobě diskusních skupin, konverzačních kroužků, organizovaných výletů, procházek po městě, návštěv koncertů, účasti ve sportovních, divadelních a hudebních skupinách atd.

Přistěhovalci mají rozmanitou potřebu informací, proto by bylo třeba zřídit ve státní režii oficiální, profesionální specializovaná poradenská místa pro otázky integrace, obsazená osobami, které mají samy migrační zkušenost a již prošly procesem adaptace a učení. Takoví poradci pro otázky integrace mohou být autentickými a kompetentními kontaktními partnery pro migranty a uprchlíky a mohou pomoci vyplnit mezery ve vědomostech týkajících se přijímající společnosti nebo uvést na pravou míru případná nedorozumění. Dosud se setkáváme pouze s izolovanou (různě kvalitní) nabídkou ze strany občanské společnosti na dobrovolném základě, což zdaleka nemůže pokrýt aktuální potřeby. 


\section{K procesu osvojení němčiny}

Právní nárok na (bezplatné) kurzy němčiny mají pouze osoby s oficiálně přiznaným azylem. Žadatelé o azyl nemají nárok na bezplatné kurzy ani nesmějí pracovat, na definitivní rozhodnutí o udělení azylu však jsou nuceni v průměru čekat mnoho měsíců (až několik let). Financování placených kurzů němčiny musí zpravidla převzít humanitární organizace nebo soukromé osoby. Stát tedy přenáší úkoly, za které je v zásadě sám odpovědný, na občanskou společnost, a tím šetří značné finanční a personální prostředky. Nejistá a dlouhodobě nejasná perspektiva, pokud jde o setrvání v zemi, má negativní dopad na motivaci uprchlíků učit se německy. Proč se věnovat intenzivnímu studiu němčiny, když nakonec stejně hrozí vyhoštění?

Celková nabídka kurzů němčiny není dostatečná kvantitativně (čekací seznamy a přeplněné kurzy) ani kvalitativně. Příslušné kurzy nabízejí zejména takzvané lidové univerzity (Volkshochschulen), charitativní organizace a komerční jazykové školy. Je třeba řešit různé jazykově pedagogické úkoly: pokud jde o předchozí vzdělání uprchlíků, sahá jejich rozpětí od osob bez školního vzdělání/analfabetů až po absolventy univerzit. Navíc řada vyučujících nemá profesionální vzdělání (pro němčinu jako cizí jazyk). Mají pouze omezený metodický repertoár, neumějí se přizpůsobit konkrétním požadavkům nebo zvolit adekvátní přístup a využívají určité naučené rutinní postupy a šablony, často jdoucí proti předpokladům a potřebám účastníků kurzů. Nezřídka se praktikují zcela zastaralé a nepatřičné didaktické metody, při kterých je např́iklad kladen důraz na gramatickou terminologii (kterou často vůbec nelze aplikovat na mateřské jazyky studentů) a formální jazykovou správnost, je však zanedbávána výslovnost, vyučuje se slovní zásoba v běžném životě nevyužitelná a potřebná komunikativní kompetence pro každodenní život přichází zkrátka. Když je němčina zároveň vyučovacím a cílovým jazykem i metajazykem (jazykem, v němž se podává vysvětlení), problémy se kumulují: všeobecně řečeno je sémantizace abstraktních pojmů mnohem obtížnější než u konkrétních výrazů, které lze s dostatečnou jednoznačností vysvětlit např́íklad pomocí obrázků. Totéž platí i pro slova s převážně gramatickou funkcí, komplexní syntaktické či sociokomunikativní konstrukce, ale i pro zdvořilostní vyjadřování (používání tykání a vykání), pozdravy apod. Podání a vysvětlení gramatických a sociokomunikativních jevů výhradně prostřednictvím němčiny jako metajazyka je často vzhledem k nedostatečným znalostem němčiny, které účastníci kurzů mají, nutně neúplné, nepřesné a vede k řadě nedorozumění. Mnozí studenti také nejsou zvyklí pracovat se slovníky či referenčními příručkami a místo toho se spoléhají na chatrné (a nezřídka chybné) údaje ze služby Google Translate. V takových případech by bylo užitečné mít oporu v příslušném mateřském jazyce, aby bylo možné ozřejmit a rozpracovat jemné významové rozdíly a zvláštnosti německých jazykových struktur. Na tomto místě by 
byly smysluplné kontrastivní či konfrontativní didaktické postupy. K tomu by však vyučující potřebovali příslušné vzdělání, nejvhodnější by k tomu byli dvojjazyční učitelé s kombinací němčiny a původního jazyka. Potenciál by byl zajisté k dispozici: lze předpokládat, že se mezi uprchlíky vyskytují i učitelé, kteří by se beze všeho mohli tohoto úkolu zhostit a mohli by se věnovat i primární alfabetizaci.

\section{Analfabetismus a úroveň ovládání původního jazyka}

I v evropských společnostech existuje určitý nemalý podíl (tzv. funkčních) analfabetů (v Rakousku se jejich počet odhaduje na několik set tisíc). Jedná se tedy o osoby, které se navzdory školní docházce nedokázaly naučit číst a psát nebo získané schopnosti později opět (do velké míry) zapomněly. Pro tento okruh osob jsou již po řadu let nabízeny zejména na lidových univerzitách speciální alfabetizační kurzy. Zásadní rozdíl oproti analfabetickým přistěhovalcům spočívá v tom, že „domácí“ analfabeti ovládají němčinu a potřebují si „pouze“ (znovu) osvojit kulturní techniku čtení a psaní, což je samo o sobě dost těžké. U uprchlíků/migrantů je problém analfabetismu komplexnější. $V$ jednodušších případech pouze neovládají latinskou abecedu, například jsou alfabetizováni na základě arabského písma, a latinku je tedy lze naučit v rámci výuky němčiny. Mnohem komplikovanější je př́ípad, kdy dotyčné osoby nebyly alfabetizovány vůbec, protože nikdy nechodily do školy. Zde je třeba přistoupit k primární alfabetizaci, kterou lze provést pouze $\mathrm{v}$ mateřském jazyce (perština, paštó, kurdština, arabština apod.). Může se však stát (a není to nijak ojedinělé), že dotyční neovládají standardní jazyk, ale hovoří dialektem či menšinovým jazykem, který nemá psanou podobu. V takovém př́ípadě si musejí jako mluvčí dialektu osvojit (psaný) standardní jazyk (výslovnost, funkci písmen, ortografii, gramatiku, rozšiřující slovní zásobu atd.), aby mohla proběhnout jejich primární alfabetizace. Ten, kdo nebyl alfabetizován, kdo nenavštěvoval školu, nemá také zkušenosti se zacházením s psacími potřebami, nemá rozvinutou jemnou motoriku a - ještě obecněji - vůbec se nenaučil, jak se učit, atd. To znamená, že primární alfabetizace, kterou je třeba dodatečně provést, neřeší pouze lingvistické úkoly, ale v určitém rámci musí zahrnovat i akulturaci.

Dodatečná alfabetizace představuje velmi důležitý úkol, protože vytváří předpoklady pro další profesní vzdělávání. Alfabetizační proces je značně náročný a je třeba počítat s tím, že může trvat několik let. $V$ opačném případě tyto osoby nemohou získat kvalifikaci, která by jim umožnila materiální existenci, a zůstanou odkázány na sociální dávky.

Mnoho uprchlíků (vyskytují se výrazné rozdíly podle toho, o jakou zemi původu se jedná) neabsolvovalo více než základní školu, což často není doba delší šesti let. Je přirozené, že z pedagogického hlediska představují při výuce němčiny a dalším vzdělávání nejmenší problém osoby s dokončeným školním 
vzděláním, konkrétně s vysokoškolským vzděláním. S dosaženým vzděláním významně souvisí čtenářská gramotnost. Dovednost čtení a čtenářské zkušenosti jsou základním předpokladem pro další vzdělávání. Osoby bez dostatečných čtenářských zkušeností v mateřštině mohou tento deficit v němčině kompenzovat a dohnat jen stěží. Také nebudou schopny poznat různé spisovné stylistické varianty a textové druhy a porozumět jim. Tím jsou omezeny možnosti jejich jazykového vzdělání a další profesní kvalifikace.

\section{Role angličtiny a jiných „pomocných jazyků“}

Možnosti využití takzvaných pomocných jazyků při výuce jsou různé. Ačkoli mnoho uprchlíků má určité znalosti angličtiny, ty často nestačí k tomu, aby mohly být při osvojování němčiny výhodou. Mnohdy také vzniká problém v tom, že na základě jazykové příbuznosti mezi angličtinou a němčinou dochází k rušivým interferencím mezi oběma jazyky. Použití „pomocných jazykư“ při výuce (tj. jako metajazyka) představuje výhodu, pokud účastníci kurzu daný jazyk dobře ovládají. Takový jazyk pak může v konkrétních případech plnit funkci metajazyka efektivněji než němčina.

Nesmíme opomenout ani problematiku překladů a tlumočení určitých jazyků. Panuje velký nedostatek kvalifikovaných překladatelů a tlumočníků pro perštinu, paštó, kurdštinu a africké jazyky. Osoby s migračním pozadím, které již dlouho v zemi žijí, často fungují i oficiálně (tj. ve styku s úřady) jako překladatelé/tlumočníci, nemají však odpovídající doklad o kvalifikaci. Zda a jak dobře ještě svou mateřštinu ovládají a zda jsou skutečně schopny správně překládat, je často nejasné a fakticky nekontrolovatelné. Otázka, jakou roli v oficiálních funkcích (např. jako tlumočníci) hrají a do jaké míry jsou přitom zastoupeny jejich osobní zájmy, se př́liš neřeší. Kvalita a spolehlivost překladů a tlumočení má dalekosáhlé následky, počínaje registrací uprchlíků až po pohovory, které jsou základem pro rozhodnutí o udělení azylu. Eden Mengisová (Mengis 2015) se této otázce věnovala ve studii o překladatelích/tlumočnících z tigrajštiny (Eritrea) a zjistila nejen značné nedostatky, ale i manipulace (v extrémních př́ípadech dokonce výhrůžky a politický nátlak ze strany eritrejského zastupitelského úřadu).

Při řešení tohoto problému by alespoň do určité míry mohly pomoci moderní komunikační technologie. V rakouském zdravotnictví se v poslední době stále více prosazuje a velmi osvědčuje takzvané video-tlumočení (prostřednictvím videa je připojen tlumočník, který překládá mezi lékařem a pacientem). Analogicky by při komunikaci mezi úřady a uprchlíky bylo možné také propojení s německými a švýcarskými jazykovými experty, čímž by se rozšíril okruh dostupných specialistů. Zde je zřejmé, že bylo a je chybou omezování a rušení studijních oborů zaměřených na orientální jazyky, či dokonce jejich difamace, nebot́ osob, které dobře ovládají mimoevropské jazyky, je nedostatek. 


\section{Školou povinní migranti - rakouská praxe}

V Rakousku platí už po mnoho let princip zařazování do školy v závislosti na věku s přechodnými lhůtami (to znamená, že žáci mají dva roky čas na složení potřebných zkoušek). Správnost tohoto přístupu potvrzují dobré zkušenosti. Spor o vlastní (tj. segregované) tř́ídy uprchlíků, který vyvolaly pravicové strany, pramení z populistické snahy profilovat se za každou cenu. Pedagogové se zkušenostmi s migrací tento koncept obecně odmítají. To však dogmatické politice, která je rezistentní vůči poznatkům, nebrání v tom, aby tento cíl přesto sledovala, především proto, že její představitelé ve skutečnosti usilují o segregaci a diskriminaci, nikoli o integraci migrantů s cílem rovnoprávného soužití ve společnosti.

Zařazení do školy v závislosti na věku však končí dosažením 15 let. Počínaje tímto okamžikem už mládež nemá nárok na školní docházku, a tedy v podstatě žádnou šanci na dodatečné doplnění povinné školní docházky. V důsledku toho mladí lidé ani nemají možnost naučit se například řemeslu, nebot předpokladem vyučení je ukončená povinná školní docházka. Tato neflexibilita rakouského školství představuje vážný problém, s dalekosáhlými sociálními následky na cestě k integraci.

\section{„Integrace“ jako učební cíl?}

Může být „integrace“ předmětem pedagogického programu, školních osnov? Lze „integraci“"vyučovat/učit se (jako školní předmět)? Problém spočívá již ve vlastním pojmu. Jak lze popsat či definovat „integraci“? Co všechno je předmětem integrace a kdy je dokončená? Příslušné diskuse probíhají rozporuplně. Historické zkušenosti jsou často ignorovány. Německo po roce 1945 přijalo a integrovalo 12 milionů lidí (odsunutých z východní Evropy), Rakousko zažilo velké přistěhovalecké vlny již v 19. století (zejména do Vídně přicházeli Češi, Židé atd.). Z ekonomického a demografického hlediska migrace dlouhodobě přinášela výhody, $v$ žádném případě nevedla k takzvanému etnickému či kulturnímu přecizení, jak se snaží neustále zdůrazňovat nacionální nostalgici a agitátoři. Naopak při pohledu na historii vlastní rodiny si člověk uvědomí, že národní a kulturní homogenita byla v minulosti stejně jako dnes fikcí, a navíc špatným ideálem (Saunders 2012).

Jak již bylo řečeno, osvojit si cizí jazyk na vysoké úrovni trvá řadu let. Ne všichni přistěhovalci během života dosáhnou takové úrovně, aby mohli bezchybně komunikovat $\mathrm{v}$ písemném a ústním projevu. Mnoho z nich nedokáže překročit určitý stupeň jazykových dovedností. S jakým časovým rámcem ale musíme při integraci počítat?

Politici v souvislosti s integrační problematikou vymysleli povinné intenzivní integrační kurzy, v nichž má být probrán katalog evropských „hodnot“ (počínaje demokracií, přes práva žen, až po třídění odpadu). V Bavorsku jsou 
k tomu vyhrazeny tři hodiny, v Rakousku osm hodin. Metodicky lze tento prrístup přirovnat $k$ výuce jazyka, při které jednou intenzivně vysvětlíme gramatická pravidla a budeme věřit, že to stačí. Nácvik jazykových, popřípadě společenských konvencí probíhá v (životní) praxi na základě metody pokus a omyl, při které je třeba řadu věcí jednoduše vyzkoušet a která připouští a musí připouštět - mnoho chyb. Odhlédneme-li od vnucené pochybné pedagogické stránky a problematiky teorie učení, vycházejí politici z předpokladu, že uprchlíci přicházejí s cílem úmyslně porušovat normy. V současnosti jsme ale svědky toho, jak jsou demokratické hodnoty neustále podrývány - hořící azylová stř̌ediska a štvavé výroky hnutí Pegida, Alternativy pro Německo (AfD) či jiných radikálních pravicových politických skupin. Vědomé směšování uprchlické problematiky s islamistickým terorem je úmyslným štvaním a nástrojem všeobecné diskriminace uprchlíků. Není divu, že se mladí uprchlíci vzhledem ke konkrétním životním podmínkám (hromadné ubytovny, zákaz práce, absence společenského kontaktu, odmítání ze strany obyvatelstva, ztráta perspektivy atd.) dopouštějí protizákonného jednání (krádeže, sexuální útoky apod.). Předsudky vůči přistěhovalcům a uprchlíkům a odmítání těchto osob doprovázejí všechny imigrační vlny, konzervativní a nacionalistické politické strany opakovaně zneužívají přistěhovalectví vnitropoliticky k vlastním účelům. Využívají předsudky, více či méně subtilně štvou proti cizincům, azylantům, znevažují humanitární pomoc, požadují mimořádně restriktivní zvláštní zákony atd. V praxi při tom často pozorujeme, že se uchylují k nacistickým heslům a nacistické rétorice. Na tomto diskurzu je nebezpečné, že jazyk populistické a rasistické agitace je stále útočnější, je společností akceptován a oproštuje se od všech dosavadních společenských tabu.

Integrace je proces, který trvá několik let a závisí na stupni vzdělání, sociálním statusu přistěhovalců atd. Tento proces v podstatě nelze zkrátit. Integrace představuje dialog mezi domácím obyvatelstvem a přistěhovalci. Společenské „hodnoty“ jsou přijímány formou dialogu, respektive „osvojovány“ tím, že přistěhovalci v novém prostředí konfrontují vlastní s cizím a adaptují si to, co je nové. Naopak i domácí obyvatelstvo se od přistěhovalců učí, že „kultura“ není konstantní, že podléhá řadě změn a migrace samozřejmě zanechává stopy. Kontakt mezi domácím obyvatelstvem a cizinci se projevuje v jazyce a v řadě oblastí každodenní kultury. V procesu integrace cizinců se mění rovněž kultura domácího obyvatelstva, tak tomu bylo i dříve. Podíváme-li se na stopy kontaktů s cizím živlem v kulinářství, v hovorovém jazyce, u jmen apod., můžeme si udělat názornou empirickou představu o účinnosti vzájemně působících mechanismů. Z populistických a demagogických důvodů se tyto procesy vzájemného ovlivňování často vůbec neberou v potaz, nebo jsou dokonce popírány či démonizovány (řeč je o odcizení, převaze cizího). Integrace znamená pro přistěhovalce vstup do nové společnosti a pro domácí obyvatelstvo ochotu přijmout „nové obyvatelstvo“ jako rovnoprávné. 
Integrace je dlouhodobý proces učení, v němž si přistěhovalci i domácí obyvatelstvo dělí role. Přistěhovalci se orientují podle každodenního života, podle provozované praxe, podle vzorů a příkladů a možností účastnit se společenského života, které jim jsou poskytnuty. Vycházíme-li z toho, že po dvou až pětiletém pobytu lze znalosti němčiny označit za dobré (což nevylučuje nedostatky, mezery a chyby), je zřejmé, že integrační proces může trvat celá desetiletí. Vždyt' kdo umí „opravdu perfektně“ německy, kdo je „opravdu perfektně“ integrován? Ačkoli se jedná o velmi vágní formulaci, na otázku týkající se jazykových dovedností lze pravděpodobně odpovědět snáze a objektivněji než na otázku ohledně míry integrace. Rovněž je jisté, že jazykové chyby, prohřešky proti gramatickým pravidlům či proti praktickým jazykovým konvencím, lze tolerovat spíše než přestupky proti konvencím společenským.

Také u integračního procesu (stejně jako v případě učení obecně) hraje roli motivace, kterou lze negativně či pozitivně ovlivnit různými okolnostmi. K negativním faktorům patří zejména nedostatečná akceptace cizinců domácím obyvatelstvem a chybějící perspektiva trvalého (neomezeného) pobytu s možností sloučení rodiny. O této otázce se v současnosti diskutuje pod názvem „azyl na dobu určitou“ (3 roky), přičemž tento návrh odmítají i hospodářské kruhy. Začlenění do pracovního a výdělečného procesu je v dnešní době vzhledem $\mathrm{k}$ hospodářské stagnaci a vysoké nezaměstnanosti domácího obyvatelstva velmi obtížné, přičemž zde zvláště tvrdý oříšek představuje otázka kvalifikace a vzdělání uprchlíků. Je třeba investovat značné prostředky do školení, kvalifikačních kurzů apod., aby nedošlo k dalšímu explozivnímu nárůstu celkové nezaměstnanosti (u domácího obyvatelstva i přistěhovalců).

\section{Závěr}

V průběhu integračního procesu v německy mluvících zemích má osvojování němčiny prioritní postavení. Oficiální politika postupuje v oblasti integrační práce bezkoncepčně a bezradně, projevuje nedostatek profesionality a má sklon k povrchním (většinou populistickým) ad hoc řešením. Absurdně a v rozporu s veškerou empirií předpokládá, že většina uprchlíků a přistěhovalců se úmyslně vyhýbá němčině a že tak vědomě a cíleně usiluje o místo na okraji společnosti. Občanská společnost oproti tomu jedná výrazně kompetentněji a ochotněji, potřebuje však v řadě oblastí podporu státu. Důležitější než intenzivní kurzy v otázkách integrace by byla poradenská místa obsazená již integrovanými odborníky, kteří ovládají mateřský jazyk přistěhovalců a mohou poskytnout spolehlivé informace o všech oblastech každodenního života, například v otázkách pracovního práva, bydlení, nájmu, škol, úvěrů atd. V žádném případě nelze popírat, že se mezi uprchlíky a migranty vyskytují lidé, kteří v zásadě (z nejrůznějších důvodů) odmítají sociální 
přizpůsobení, tyto skupiny osob však představují absolutní menšinu. V případě vyloženě nepatřičného a protizákonného chování jsou k dispozici příslušné státní sankce a mocenské prostředky. Politika se dnes však ubírá zcela odlišným směrem: intenzivně hledá možnosti, jak přenést integraci uprchlíků na jiné země. Navzdory veškerému ujištování o křestanských hodnotách jsou to postoje nesolidární, pro dotyčné osoby nelidské a pro humanistické a demokratické cíle EU destruktivní.

Květen 2016 